\title{
Developing Creativity and Entrepreneurship of Undergraduate Students through a Field Trip Overseas
}

\author{
Mayuree Suacamram \\ Bangkok University, Thailand, mayuree.s@bu.ac.th
}

This study aimed to explore the operation of the program (the field trip and the selection process to select eligible program participants) and to compare the differences in terms of developing creativity and entrepreneurship between student groups. The key informants consisted of 4 groups comprising one teacher who supervised the trip, 12 students who joined the field trip in New York, 12 students who passed the first round of the selection, and 12 students who didn't join the program. The research instruments were a scoring rubric, a questionnaire, and an interview. The obtained data was then analysed using content analysis, Wilcoxon and Kruskal-Wallis. The findings revealed the activities in the selection process which consisted of a workshop to generate ideas, a new method which consisted of a contest in pair to solve a problem, and the program final judgment based on giving a presentation and the stress-free atmosphere. Regarding the field trip, the activities and locations focused on 4 areas: communication arts, photography, designs and fashions, and drama and performing arts. The results show that visiting the museum and a Broadway show led to developing creativity and inspiration. The teacher also played a role in developing creativity and giving inspiration. Moreover, student who joined the field trip showed a statistically significant increase in both creativity and entrepreneurship. In addition, statistically significant differences were found in creativity among the three student groups.

Keywords: developing creativity, developing entrepreneurships, field trips, activity in selection process, New York

\section{INTRODUCTION}

Creativity and entrepreneurship are two main attributes that will make undergraduate students become successful in their future profession. According to Park and Han (2016), a college student's creativity affects career preparation behaviour. Higher creativity results in a higher level of career readiness. Meanwhile, entrepreneurship is deemed important in all fields of study nowadays; it enables students to create different ideas from different perspectives in solving problems (Guilford, 1968; Torrance, 2008; VandenBos, 2007). When they graduate, they will be able to create new things and take

Citation: Suacamram, M. (2019). Developing Creativity and Entrepreneurship of Undergraduate Students through a Field Trip Overseas. International Journal of Instruction, 12(1), 591-606. https://doi.org/10.29333/iji.2019.12138a 
risks in their jobs and business. Bangkok University, therefore, puts emphasis on these two attributes and promotes them as the university's identities. The university aims to develop its graduates to develop the two attributes as their strong suit. With both of the attributes, the students will possibly be able to become a new generation of creative entrepreneurs with bright future (Bangkok University, 2015). So, they will be capable of achieving their dreams.

Developing creativity and entrepreneurship can be achieved both inside and outside of the classroom. Adams (2005) indicated 25 steps in developing learners' creativity. It is concluded that learners must have faith in their capacities and learning activities must help generate ideas and open up learners' mind allowing them to see a role model or good practice. It is also necessary to reduce activities that would block learners' ideas and create thought-provoking learning atmosphere.

Positive learning environments were related to intrinsic motivation and creativity (Tsai, Horng, Liu, Hu, \& Chung, 2015). The barriers of creativity development include the low level of students' awareness of creative activity, mismatch of curricula and extracurricular activities, offered by modern universities, needs and demands of students (Khairullina, Bakhtizin, Gaisina, Kosintseva, \& Belonozhko, 2016).

As for developing entrepreneurship, Sinkovec and Cizeij (2013) specified that a component of developing entrepreneurship includes putting emphasis on the key basic traits such as creativity, risk taking, confidence and independence, encouraging learners to be aware of being their own boss, integrating teaching methods that allow learners to gain hand-on experience in real business, and providing knowledge about basics of business and preparation for doing a business.

According to the above concepts, it is obvious that relying only on typical classroom courses in a curriculum is not enough to bring about success in developing creativity and entrepreneurship. In this regard, providing students with outside class activities is deemed necessary. Students who go on a field trip or pay a visit to different locations will increase learning experience and develop creativity (Kim et al, 2015; Riegel \& Kindermann, 2016). Students who get involved in real life scenarios, in practical activities and in the conducive environment will increase entrepreneurship skills (Maxwell, Stephen, Hezekiah, Paul, \& Oyafunke-Omoniyi, 2018; Shamsudin, Al Mamun, Nawi, Nasir, \& Zakaria, 2016). With this in mind, our university has provided some other extra-curricular activities to promote these two attributes and encourage passion of students.

Among many activities, Bangkok University has been awarding a grant to sponsor students to go on a field trip in New York to learn and enlarge their visions in New York, U.S.A. Offering a grant for a field trip in New York or the BU to New York program aimed to develop creativity and entrepreneurship in their students. The program allowed the students to come up with ideas about creating their own future.

The selected students who received the grant will a chance to visit many places and do various activities in New York for 8 days (see details of the activities in the appendix). 
The students would have a chance to participate in a variety of hand-on activities and learn various concepts such as photography, creative digital marketing, display design, creative branding and experience to think outside of the box. Moreover, the process of developing creativity and entrepreneurship actually start from the program participant selection process. In the first round of the selection, the candidates were be assigned to present their ideas to transform Bangkok. In the second round, they were required to attend a training workshop and later they went on a field trip in New York. These activities were all designed to promote creativity and entrepreneurship in students. After the program had ended, it was questioned whether the field trip in New York could encourage the development of creativity and entrepreneurship in students. Therefore, this study was conducted to examine the results of the program.

\section{REVIEW OF LITERATURE}

Relevant concepts and documentation have been reviewed and presented in four topics as follows: 1) Assessing and developing creativity in the learners 2) Assessing and developing entrepreneurship in the learners 3) BU to New York Program 4) Related research studies.

\section{Assessing and Developing Creativity}

Creativity is cognitive ability to create different ideas from different perspectives. It is an ability to extend your thinking (Guilford, 1968; Bangkok University, 2015). When solving problems or producing or developing work, theories, techniques, or ideas, (Guilford, 1968 ; VandenBos, 2007 ; Torrance, 2008), creativity is personal imagination or expression (VandenBos, 2007) resulting from integrating knowledge and experience to form a concept, to set up an hypothesis and then put it to test to make a new discovery (Torrance, 2008). Creativity also means to initiate an alternative, and to create a new product or a new way of working to appropriately and practically handle a problem (Bangkok University, 2014). However, serendipity is also another definition of creativity (Reich et al, 2012).

Adams (2005) indicates 25 steps that can promote creativity in learners. The steps are categorized based on features of creativity development as seen in Table 1. 
Table1

Developing Creativity

\begin{tabular}{|c|c|c|}
\hline Main component & Sub-components & Steps \\
\hline \multirow[t]{2}{*}{ 1. Basic attributes } & Prerequisites & $\begin{array}{l}\text { 1. Modelling creativity } \\
\text { 2. Building self-efficiency }\end{array}$ \\
\hline & $\begin{array}{l}\text { Add complex } \\
\text { techniques }\end{array}$ & $\begin{array}{l}\text { 3. Teaching self-responsibility } \\
\text { 4. Promoting self-regulation } \\
\text { 5. Delaying gratification }\end{array}$ \\
\hline \multirow[t]{4}{*}{$\begin{array}{l}\text { 2. Techniques to } \\
\text { promote creativity }\end{array}$} & Basic techniques & $\begin{array}{l}\text { 6. Questioning assumptions } \\
\text { 7. Defining and redefining problems } \\
\text { 8. Encouraging idea generation } \\
\text { 9. Cross-fertilizing ideas }\end{array}$ \\
\hline & Tips for teaching & $\begin{array}{l}\text { 10. Allowing time for creative thinking } \\
\text { 11. Instructing and assessing creativity } \\
\text { 12. Rewarding creative ideas and products }\end{array}$ \\
\hline & Use role models & $\begin{array}{l}\text { 13. Use profiles of creative people } \\
\text { 14. Encouraging creative collaboration } \\
\text { 15. Imagining other viewpoints }\end{array}$ \\
\hline & $\begin{array}{l}\text { Allowing long-term } \\
\text { perspectives }\end{array}$ & $\begin{array}{l}\text { 16. Growing creatively } \\
\text { 17. Proselytizing for creativity }\end{array}$ \\
\hline \multirow[t]{2}{*}{$\begin{array}{l}\text { 3. Creating } \\
\text { appropriate } \\
\text { atmosphere and } \\
\text { environment }\end{array}$} & $\begin{array}{l}\text { Explore the } \\
\text { environment }\end{array}$ & $\begin{array}{l}\text { 18. Recognizing environmental fit } \\
\text { 19. Finding excitement } \\
\text { 20. Seeking stimulating environments } \\
\text { 21. Playing to strengths }\end{array}$ \\
\hline & Avoid roadblocks & $\begin{array}{l}\text { 22. Encouraging sensible risks } \\
\text { 23. Tolerating ambiguity } \\
\text { 24. Allowing mistakes } \\
\text { 25. Identifying and surmounting obstacles }\end{array}$ \\
\hline
\end{tabular}

\section{Assessing and Developing Entrepreneurship}

Entrepreneurship means having motives to determine and pursue opportunities for value-added production by analysing economic, social and cultural situations. Entrepreneurship consists of the following sub-capabilities: self-management, seeking and grabbing opportunities, turning ideas into practice, thinking outside the box, risk management and taking on responsibility, creating values and products and project management (Bangkok University, 2015). Entrepreneurship can be divided into three parts comprising risk taking, innovative ideas and proactive behaviour (Bolton \& Lane, 2011).

The survey results from top undergraduate entrepreneurship programs found that intensive courses will make students more likely to be entrepreneurs than general courses that emphasize learning theories (Mandel \& Noyes, 2016). Therefore, developing entrepreneurship should focus more on practice which consists of at least one of the following components (University of Oxford, 2015).

1. Be attentive to skills and attitudes that are basically involved with entrepreneurial behaviours and thinking such as creativity, risk taking, confidence and independence. 
2. Encourage learners to realize that it is possible that they can be their own boss and an entrepreneur.

3. Employ hand-on teaching methods which take the students to learn from doing activities outside of the classroom gaining experiences that are linked to the real business world or local community.

4. Prepare skills needed for basic business and for being their own boss or selfmanagement and basic knowledge about how to start and develop a successful business.

\section{BU to New York Program}

The idea of this program was originally initiated by the senior associate president of Bangkok University's observation: why highly capable and skilled Thais would rather work and create their success in New York than their home country, Thailand. The BU to New York program aimed to develop creativity and entrepreneurship in students. The first grant to join a field trip in New York was given in 2014. The operation process was divided into two main steps: 1) selection process 2) field trip activities in New York. The details are explained below:

1. There were two rounds of the selection process. The first round was a concept contest. The topic of the contest was "it is time for you to transform Bangkok to be a city of ideas with your ideas". The contest selected 80 people. The second round was organizing a training workshop. There were four groups. In the first round, eight firstyear students were selected. In the second round, four students of the 2nd-4th year students were selected. The total of the students who were selected to join the field trip in New York was 12 students.

2. Field trip activities in New York provided creative learning opportunities in various areas: photography, creative digital marketing, display design, creative branding and experience to think outside of the box. It was an eight-day trip and the learning activities started from day 3 to 7 . A list of location visits is provided in the appendix.

The framework used to design the BU to New York Program was relevant to the concept of developing creativity and it can be divided into three main stages:

2.1 Selecting students who have the basic attributes.

2.2 Using some techniques to promote creativity focusing on hand-on learning experience and studying from role models and allowing long-term perspectives.

2.3 Creating and encouraging learning atmosphere---taking the students to learn in New York which is the city of ideas in United States.

\section{Related Research Studies}

According to Riegel and Kindermann (2016), studies about learning outcomes of undergraduate students learning from field trips show that learning outcomes from field trip learning experience are higher than the outcomes from classroom learning. Students like experiential learning such as going on a field trip, paying a visit to different locations, etc. Movies and songs are suitable teaching materials to develop creativity 
and personalities (Kim et al, 2015). Going on a field trip to visit an art museum has positive effect on students' critical thinking (Kisida et al, 2016). It can be concluded that going on a field trip allows the students to develop their thinking abilities including creativity.

As for studies concerning creativity, Karpova, Marcketti and Barker (2011) studied the effectiveness of creativity lessons. They used exercises to assess before and after the lessons. The lessons consisted of 4 modules including 1) definition of creativity 2) awareness and seeking for opportunities 3) forming concepts and 4) assessing creative ideas. After the sample group completed all of the 4 modules, the results showed that the post-test result of the creativity test (Torrance test) was higher than the pre-test.

Moreover, many previous studies reveal how entrepreneurship could be developed. Maxwell, Stephen, Hezekiah, Paul, and Oyafunke-Omoniyi (2018) found that the engagement of real life scenarios in practical activities helped to motivate the development of the drive and commitment in entrepreneurship. In another study, the holistic and well-planned entrepreneurial programs, the conducive environment and ecosystem were found to be important for entrepreneurship development. (Shamsudin, Al Mamun, Nawi, Nasir, \& Zakaria, 2016). Results from a study revealed that the main factor contributing to entrepreneurial intention is belief in one's efficacy, risk taking, goal orientation, proactive behaviours, innovativeness, attitude toward being an entrepreneur, behavioural control, family background, and supportive environment (Remeikiene, Startiene \& Dumciuviene, 2013 ; Shamsudin, Al Mamun, Nawi, Nasir, \& Zakaria, 2017)

Based on the review of the related literature above, the following is the framework for this study.

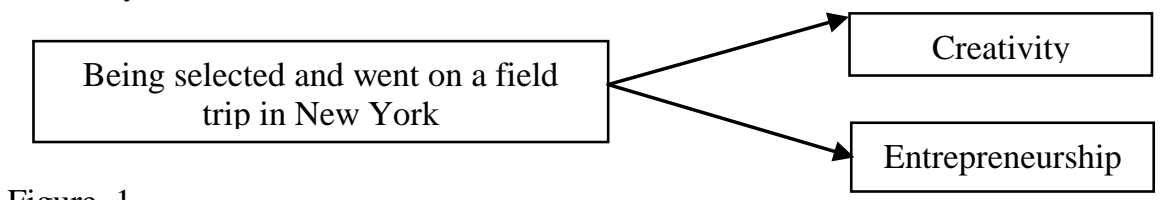

Figure 1

Framework of the Study

The current study contains three main objectives as follows:

1. To explore the operation of the BU to New York program: the field trip activities and the selection process

2. To examine the results of developing creativity and entrepreneurship in students who were selected to join the field trip in New York

3. To compare creativity and entrepreneurship of students who were selected to join the field trip and those who didn't get selected to go to New York

The findings will confirm the outcomes of the program and shed some light on how to improve the program in the future. The results of the project may be useful to other universities that focus on developing students' creativity. 


\section{METHOD}

This study is mixed methods research aiming to achieve in-depth research findings. The researcher collected and analysed both quantitative and qualitative data to confirm the findings. The details of the key informants, variables, data collection and data analysis are presented as follows:

\section{Participants}

The key informants were divided into 4 groups: 1) one teacher who supervised the trip. 2) student participants who were selected to join the field trip in New York 3) students who passed the first round of the selection process. The criterion to select the key informants in the third group was students who have the same gender, year of study, and field of study are similar to the students in the second group and 4) students who didn't join the program. The criterion to select the students in the fourth group was students who are close friends of the second group and were recommended by the second group. There were 12 people in each of the group 2-3. The details of the key informants in group 2 and 3 are presented in table 2 .

Table 2

Details of the Respondents Group 2 and 3

No Group 1: Those who were selected to

. $\quad$ join the field trip in New York Group 2 : Those who didn't get selected

\begin{tabular}{lllllllll} 
& NAME & Gender & Year & School & NAME & Gender & Year & School \\
\hline 1 & Big & Male & 4 & CA & In & Male & 3 & CA \\
\hline 2 & Nop & Male & 3 & CA & Pui & Male & 3 & CA \\
\hline 3 & B & Female & 1 & CA & Film & Male & 1 & CA \\
\hline 4 & Ken & Male & 1 & CA & Poster & Male & 1 & CA \\
\hline 5 & Nate & Male & 1 & CA & Om & Male & 1 & CA \\
\hline 6 & Aun & Male & 1 & CA & Arm & Male & 1 & CA \\
\hline 7 & Yot & Male & 1 & BUI & Dream & Male & 1 & BUI \\
\hline 8 & Dis & Male & 3 & FA & Not & Male & 3 & FA \\
\hline 9 & Prang & Female & 3 & FA & Ping & Female & 3 & FA \\
\hline 10 & Bank & Male & 1 & ACH & O & Female & 1 & ACH \\
\hline 11 & Pear & Female & 1 & ACH & Mod & Male* & 1 & ACH \\
\hline 12 & Blue & Male & 1 & SEM & Peung & Female* & 1 & SEM \\
\hline
\end{tabular}

Note: $\mathrm{CA}=$ Communication Arts, BUI = Bangkok University International, FA = Fine Arts, $\mathrm{ACH}=$ Architecture, SEM = Entrepreneurship $\quad *$ gender doesn't match with group 1

Moreover, when considering the grade point average and the educational level of the parents of both the students who went on the field trip and those who didn't, the result showed that there is not much difference in terms of their grade point averages (MannWhitney $=56.5, p=0.371)$. As for the educational level of the parents, the result revealed that most of the parents whose kids went on the field trip hold a high school diploma and undergraduate degree while those whose kids didn't get selected to go on the field trip hold an undergraduate and master's degree. 


\section{Instrumentation}

As for the outcome variables and measurement, the study focuses on examining the development of creativity and entrepreneurship of the students who received the BU to New York grant and those who didn't. The research instruments were a scoring rubric, a questionnaire, and an interview. The two main variables are creativity and entrepreneurship. Both of the variables are defined and the measurements are described as follows:

Creativity means opening up to a perspective in a situation, coming up with and initiating alternatives/ new methods appropriate/acceptable for a particular situation/problem. Creativity consists of 3 components: 1) synthesizing 2) analysing 3) taking an action. Creativity can be assessed by self-assessment using the 4-level creative thinking rubric evaluation form created by Association of American Colleges and University (2015) and interview with the students.

Entrepreneurship means having a motivation to seek for opportunities to add a new value, having courage to take risks to be an initiator by searching for and grabbing opportunities, transforming concepts into action. Entrepreneurship can be assessed by interviewing students and using an entrepreneurship measurement scale created by Bolton and Lane (2011). There are three items used for measuring entrepreneurship: 1) innovativeness 2 ) proactiveness 3 ) risk taking. The measurement consists of 10 items. The format of the measurement is a four-rating Likert scale: to indicate level of agreement: totally agree to totally disagree.

\section{Data Collection}

Data collection started when the researcher contacted the teacher who had supervised and organized the program and the students individually to make appointments to collect data. The researcher collected data by interviewing the key informants to assess creativity and entrepreneurship. Furthermore, the researcher asked the students to complete the 4-level rubric evaluation form to assess their creativity and entrepreneurship.

\section{Data Analysis}

As for data analysis, the researcher used each type of statistical tools to analyse the data to respond to each of the objectives. Regarding the first objective, content analysis was used to study the program operation. As for the second objective, content analysis, frequency, percentage, standard deviation, and Wilcoxon Test were used to examine the results of developing creativity and entrepreneurship in the students. To find out the answers for the third research objective, content analysis and Kruskal-Wallis test were used to compare between creativity and entrepreneurship of the students who got selected to join the field trip in New York and those who didn't. 


\section{FINDINGS}

\section{Results Regarding the First Research Objective \\ Results of the selection process}

Regarding the selection process, the results came up with three kinds of activities:

1) A training workshop which aimed to generate ideas for advertising and provide a new teaching method to stimulate learning

2) A contest which had 3 components comprising students who were allowed to pair up voluntarily to solve a given problem within 1 hour, 5 questions concerning product advertising ideas that were used to evaluate the students' ideas

3) The final judgment which was made mainly based on presenting ideas, not on the format of the presentation and how to present ideas

The atmosphere in general was not stressful and the students who passed the first round learned to adjust themselves and successfully developed friendship while doing the activities.

In addition, suggestions from students who joined the selection process are as follows:

1. Some break time should be provided after the contest.

2. The number of days and time for each activity should be extended especially for time to do the workshop.

3. Some concern was raised about the final round of the contest. Something should be done to maintain the fairness of the contest. For example, some students were unable to finish their final products but won the contest. Therefore, it would be better if there was more than one final round.

\section{Results of the field trip in New York}

The program organizer had planned to complete 6 types of activities. However, after the field trip, only 4 types of activities were successfully completed: 1) activities concerning communication arts and advertising 2) activities regarding photography 3) art design and fashion activities 4) drama and performing art activities. The students gained various learning experiences by visiting many important places such as visiting art museums and watching a Broadway show. Nevertheless, activities regarding business administration could made possible as previously planned. The students didn't get a chance to visit Wall Street and 6) the students didn't join the countdown activity because they could not reach Time Square and make it in time for the countdown.

Suggestions from the students who joined the field trip are as follows:

1. The program should offer activities and visits suitable for all major students. Plus, more appropriate time should be provided for each visit.

2. The travelling time should be extended. 
3. The students should be allowed more time for shopping, especially when it comes to shopping some art products.

\section{Causal mechanism between activities and outcomes}

Based on analysis of the interview found some interesting points to indicate the causal relationship between the activities and their outcomes as described below:

1. The communication arts activity which was visiting the MOMA Museum and the MET resulted positively in promoting creative ideas and inspiration of the communication arts students.

2. The performing arts activity which was watching a Broadway show resulted positively in promoting creative ideas.

3. The training workshop during the selection process resulted positively in promoting creative ideas, transforming ideas, and giving students satisfaction. This activity was considered a highlight which was well received and able to create inspiration and idea transformation very well.

4. The selection contest resulted positively in ability to transforming ideas and giving students satisfaction. The students felt that the contest was challenging and they enjoyed the contest.

5. The teacher who had supervised the program also positively contributed to generating creative ideas, transforming ideas and creating inspiration. The teacher was able to ignite passion in the students via teaching methods and being attentive to the students.

\section{Results Regarding the Second Research Objective}

The field trip in New York could develop students in terms of creativity and entrepreneurship as below:

1. The findings from the interview revealed that some changes regarding creativity of the students were found in three areas: 1) an increase in creativity 2) enhancing ideas 3) expanding work and study opportunities. In addition, some changes regarding entrepreneurship of the students were found in three areas: 1) entrepreneurship 2) risk taking and 3) opening business opportunities for themselves.

2. As for the results of the self-assessment, a statistically significant increase in students' creativity and entrepreneurship was found $(\mathrm{P}<0.05)$ after the New York trip. The mean score of creativity increased by $92.27 \%$ (Mean $=1.81$ and 3.48) and the mean score of entrepreneurship increased by $27.51 \%$ (Mean $=2.69$ and 3.43) as seen in Table 3.

Table 3

Creativity of Students Receiving the BU to New York Grant

\begin{tabular}{|c|c|c|c|c|c|c|c|c|}
\hline & \multicolumn{2}{|c|}{ Mean } & \multicolumn{2}{|l|}{ SD } & \multicolumn{2}{|l|}{ Min-Max } & \multirow{2}{*}{$\begin{array}{l}\text { Wilcoxon } \\
\text { Test }\end{array}$} & \multirow[t]{2}{*}{$\mathrm{P}$} \\
\hline & Pre & Post & Pre & Post & Pre & Post & & \\
\hline Creativity & 1.81 & 3.48 & 0.56 & 0.38 & $1.20-3.20$ & $2.80-4.00$ & -3.063 & 0.002 \\
\hline Entrepreneurship & 2.69 & 3.43 & 0.37 & 0.34 & $2.10-3.30$ & $2.70-4.00$ & -1.063 & 0.021 \\
\hline
\end{tabular}




\section{Results Regarding the Third Research Objective}

The comparison between students who were selected to join the field trip and those who were not is discussed in terms of creativity and entrepreneurship as follows:

1. The findings from the interview showed that there was an increase in developing creativity and enhancing ideas among the students who joined the field trip and those who passed the first round of the selection process. However, those who joined the field trip received more opportunities for study and work than those who didn't get to join the field trip. For example, the students who had been selected to join the field trip were selected to do an internship at GMM Grammy Company Ltd and to receive the Creative Scholarship from Bangkok University. As for entrepreneurship, it was found out that both groups of the students had similar opinions concerning entrepreneurship and opening business opportunities for themselves. For some students, even though they didn't join the field trip, they could still develop entrepreneurship after they joined the activities in the selection process. However, higher level of risk taking was found among students who joined the field trip.

2. The results of the self-assessment revealed that statistically significant difference was found in the mean scores of all of the three student groups $(\mathrm{P}<0.05)$. The students who received the highest mean score were the students who went on the field trip (Mean = 3.48 ), the students who joined the activities in the selection process (Mean $=2.98)$ and those who didn't join the program (Mean $=2.58$ ) respectively. In terms of entrepreneurship, the results show no statistically significant difference in the mean scores of all of the three student groups $(\mathrm{P}>0.05)$. The group of students who went on the field trip and the group who joined the activities in the selection process have the same mean score $($ Mean $=3.43)$. Those who didn't join the program have lower score than the two groups above (Mean $=3.18)$ as presented in Table 4 .

Table 4

The Differences in Mean Scores of Creativity and Entrepreneurship of the Students in the Three Groups

\begin{tabular}{llllll}
\hline Variables & Student Group & Mean & S.D. & Kruskal-Wallis & P \\
\hline Creativity & Went to NY & 3.48 & 0.38 & 13.997 & 0.001 \\
& Selected to join the selection & 2.98 & 0.51 & & \\
& & & & \\
& activities & & & \\
& Didn't join the program at all & 2.58 & 0.41 & & \\
& Total & 3.05 & 0.56 & & \\
\hline Entrepreneurship & Went to NY & 3.43 & 0.34 & 2.809 & \\
& Selected to join the selection & 3.43 & 0.23 & & \\
& activity & & & & \\
& Didn't join the program & 3.18 & 0.53 & & \\
Total & 3.36 & 0.38 & & \\
\hline
\end{tabular}




\section{DISCUSSION}

The first important issue to be discussed is the development of creativity in students. Based on the findings, a statistically significant increase in students' creativity was found after the New York trip. The increase in their creativity is probably due to the features of the BU to New York program. That is, the field trip provided activities such as using hand-on activities to promote creativity, learning from role models, opening perspectives and experiences and creating suitable learning atmosphere. The result can be supported by Tsai, Horng, Liu, Hu, and Chung (2015) who state that the activities that provide positive learning environments and allow students to participate and cooperate creatively will develop creativity. The field trip also creates a new learning experience of students, which cannot be found in classroom (Riegel \& Kindermann, 2016). The features of all of the activities both during the selection process and the field trip are correspondent with Sternberg (1996)'s methods of developing creativity (Adams, 2005) which include modelling creativity, building self-efficiency, using profiles of creative people, encouraging creative collaboration, imagining other viewpoints, recognizing environmental fit, finding excitement, seeking stimulating environment, playing to strengths, growing creatively, proselytizing for creativity. The results also revealed that statistically significant differences were found in the mean scores of all of the three student groups comprising those who went on the field trip, those who selected to join the selection activities, and those who did not join the program. That is, the students who received the highest mean score were the students who went on the field trip. The current findings which show positive effects of field trips on developing creativity are consistent with the findings of Riegel and Kindermann (2016), who found that learning outcomes of undergraduate students learning from field trips were higher than the outcomes from classroom learning. Similarly, the results of students' increase in creativity are in accordance with the results found by Kim et al (2015) and Kisida et al (2016), revealing that going on a field trip allowed the students to develop their thinking abilities and creativity.

The next critical issue for discussion is the development of entrepreneurship of students who joined the field trip in New York. After the trip, these students had a statistically significant increase in their entrepreneurship. This is probably because the features of activities of the BU to New York program comply with the guideline for developing entrepreneurship as indicated by University of Oxford (2015) which is listed as follows: being attentive to basic skills and attitudes, encouraging learners to aware of being an entrepreneur, using hand-on experience based teaching methods. The current findings were found to be in accordance with the findings of Mandel and Noyes (2016) in that intensive and practice courses would make students more likely to be entrepreneurs than general courses. The engagement of real life scenarios and conductive environment motivated the development of the commitment in entrepreneurship (Maxwell, Stephen, Hezekiah, Paul, \& Oyafunke-Omoniyi, 2018 ; Shamsudin, Al Mamun, Nawi, Nasir, \& Zakaria, 2016).

Nonetheless, although the field trip in New York helped develop entrepreneurship in students, there was still another interesting issue to be addressed. When the three 
students groups (those who went on the field trip, those who selected to join the selection activities, and those who did not join the program) were compared, the results showed no statistically significant differences in the mean scores of the three groups. The group of students who went on the field trip and the group who joined the activities in the selection process have the same mean score $($ Mean $=3.43)$. Those who didn't join the program have lower score than the two groups above $($ Mean $=3.18)$. This might be because most of the activities focused on visiting art museums and places that promote creativity. The program only provided one activity, visiting Wall Street which concerns business and finance. Moreover, there are other variables affecting entrepreneurship including belief in one's efficacy, risk taking, goal orientation, proactive behaviours, innovativeness, attitude toward being an entrepreneur, behavioural control, family background, and supportive environment (Remeikiene, Startiene \& Dumciuviene,2013 ; Shamsudin, Al Mamun, Nawi, Nasir, \& Zakaria, 2017). This research cannot control these variables.

\section{SUGGESTIONS}

The current study comes up with several suggestions that may be useful for future research concerning the development of creativity through the field trip. Firstly, it is recommended that the field trip should focus more on training students' thinking and arousing passion to learn and to pursue their dreams. However, it is important that activities offered each year should always be new, exciting and effective. Secondly, the activities should be planned and designed based on desire of the students in every department. The activities should be suitable for students of all majors, not just for students of a particular major. Lastly, time for each activity should be well managed. If time given to do some activities and to visit some places is not enough, it may not lead to positive results.

\section{ACKNOWLEDGEMENTS}

This research was supported by Assoc. Prof. Dr. Tiparatana Wongcharoen, Executive Vice President for Academic Affairs. 


\section{REFERENCES}

Adams, K. (2005). The Sources of Innovation and Creativity. National Center on Education and Economy.

Association of American Colleges and Universities. (2015). All value rubric. Retrieved 1 May 2015 from http://www.in.gov/che/files/All_VALUE_Rubrics.pdf

Bangkok University. (2014). Evaluation Research for General Education. Bangkok: Bangkok University.

Bangkok University. (2015). The Origin of Creativity + Entrepreneurship. Retrieved on 3 April 2015 from http://www.bu.ac.th/admission2015/

Bolton, D. L., \& Lana, M.D. (2011). Individual entrepreneurial orientation: development of a measurement instrument. Education and Training. 54(2): 219-233.

Guilford, J.P. (1968). The nature of human Intelligence. New York: McGraw-Hill Book.

Karpova, E., Marcketti, S.B. \& Barker, J. (2011). The Efficacy of teaching creativity: Assessment of student creative thinking before and after exercises. Clothing \& Textiles Research Journal. 29(1): 52-66.

Khairullina, N., Bakhtizin, R., Gaisina, L., Kosintseva, T., \& Belonozhko, L. (2016). Development of Creative Activity of Students in the System of the Organizational Culture of the Modern University. International Journal of Environmental and Science Education, 11(4), 2171-2184.

Kim, H. J., Lee, H. S., Youn, J. J., Eom, S. J., \& Lee, J. K. (2015). A study on college students' demands for creativity and personality education as part of the general education curriculum. Indian Journal of Science and Technology, 8(S8), 29-36.

Kisida, B., Bowen, D. H., \& Greene, J. P. (2016). Measuring critical thinking: Results from an art museum field trip experiment. Journal of Research on Educational Effectiveness, 9(sup1), 171-187.

Mandel, R., \& Noyes, E. (2016). Survey of experiential entrepreneurship education offerings among top undergraduate entrepreneurship programs. Education+ training, 58(2), 164-178.

Maxwell, O. A., Stephen, I. A., Hezekiah, F. O., Paul, S. O., \& Oyafunke-Omoniyi, C. O. (2018). Entrepreneurship Curriculum Contents and Entrepreneurial Development of University Students In Nigeria. International Journal of Entrepreneurship, 22(1).

Park, M. S., \& Han, S. H. (2016). A Study on the Affect of College Students Creativity, Self-Leadership and Self-Determination on Career Preparation Behavior.

Reich, Y., Hatchuel, A., Shai, O., \& Subrahmanian, E. (2012). A theoretical analysis of creativity methods in engineering design: casting and improving ASIT within $\mathrm{C}-\mathrm{K}$ theory. Journal of Engineering Design, 23(2), 137-158. 
Remeikiene, R., Startiene, G. \& Dumciuviene, D. (2013). Explaining entrepreneurial intention of university students: the role of entrepreneurial education. In Active Citizenship by Management, Knowledge Management \& Innovation Knowledge and learning, 19-21 June 2013 Zadar, Croatia International Conference 2013.

Riegel, U., \& Kindermann, K. (2016). Why leave the classroom? How field trips to the church affect cognitive learning outcomes. Learning and Instruction, 41, 106-114.

Shamsudin, S. F. F. B., Al Mamun, A., Nawi, N. B. C., Nasir, N. A. B. M., \& Zakaria, M. N. B. (2016). Policies and practices for entrepreneurial education: The Malaysian experience. The Journal of Developing Areas, 50(5), 307-316.

Shamsudin, S. F. F. B., Al Mamun, A., Nawi, N. B. C., Nasir, N. A. B. M., \& Zakaria, M. N. B. (2017). Factors Affecting Entrepreneurial Intention Among The Malaysian University Students. The Journal of Developing Areas, 51(4), 423-431.

Sinkovec, B., \& Cizelj, B. (2013). Entrepreneurial Education \& Innovation Developing Entrepreneurial Mindset for Knowledge Economy. University of Wolverhamption.

Torrance, E. P. (2008). Thinking Creativity with Words. Forms A and B. Bensenville, IL: Scholastic Testing Service. Inc.

Tsai, C. Y., Horng, J. S., Liu, C. H., Hu, D. C., \& Chung, Y. C. (2015). Awakening student creativity: Empirical evidence in a learning environment context. Journal of Hospitality, Leisure, Sport \& Tourism Education, 17, 28-38.

University of Oxford. (2015). Teaching methods. Retrieved March 26, 2015, from https://www.conted.ox.ac.uk/L100-9

VandenBos, G.R. (2007). APA Dictionary of Psychology. American Psychological Association, Washington, D.C. 


\section{Appendix}

Field trip destinations in New York in each day

\begin{tabular}{|c|c|c|}
\hline Day & Location & Brief descriptions of each place \\
\hline \multirow[t]{2}{*}{1} & $\begin{array}{l}\text { The Museum of the Movie } \\
\text { Image }\end{array}$ & $\begin{array}{l}\text { An animation museum to showcase all kinds of animated } \\
\text { techniques and technologies. }\end{array}$ \\
\hline & Williamsburg Zone & An unincorporated community with 15162 citizens \\
\hline \multirow[t]{3}{*}{2} & $\begin{array}{l}\text { The Metropolitan Museum } \\
\text { of Art }\end{array}$ & $\begin{array}{l}\text { An art museum and library to promote art and apply art } \\
\text { to real world production and living }\end{array}$ \\
\hline & Guggenheim Museum & $\begin{array}{l}\text { An art museum and an important architectural symbol of } \\
\text { the 20th century. It was a centre of culture and } \\
\text { educational institutes and an important art museum } \\
\text { network. }\end{array}$ \\
\hline & Museum of Modern Art & $\begin{array}{l}\text { an art museum focusing on creativity, and creating ideas } \\
\text { inspiration }\end{array}$ \\
\hline \multirow[t]{5}{*}{3} & Ground Zero 9/11 & $\begin{array}{l}\text { a memorial museum about the tragedy of the terrorist } \\
\text { attacks on } 9 / 11,2001\end{array}$ \\
\hline & Wall Street & $\begin{array}{l}\text { a powerful economic and financial centre/ a big stock } \\
\text { market based on the total purchase value and NASDAQ }\end{array}$ \\
\hline & SOHO & $\begin{array}{l}\text { Previously was a residential area and an art exhibit area } \\
\text { for many artists but now is a shopping area }\end{array}$ \\
\hline & Fifth Avenue & The best and the most expensive shopping area \\
\hline & China Town & residential area of Chinese people in the US \\
\hline \multirow[t]{6}{*}{4} & $\begin{array}{l}\text { Liberty Enlightening the } \\
\text { World }\end{array}$ & $\begin{array}{l}\text { Statue of Liberty, which was a gift from France to USA } \\
\text { to celebrate their } 100 \text { year anniversary of their good } \\
\text { relationship }\end{array}$ \\
\hline & St. Patrick's Cathedral & one of ancient churches in USA \\
\hline & LEGO Shop & Lego store with innovative design \\
\hline & All Apple Store & Apple electronic gadget store \\
\hline & $\begin{array}{l}\text { Display Design (Fifth } \\
\text { Avenue) }\end{array}$ & see product displays on Fifth Avenue \\
\hline & Countdown at Time Square & $\begin{array}{l}\text { Celebrate New Year at Time Square, an intersection } \\
\text { which is the business centre in New York }\end{array}$ \\
\hline \multirow[t]{4}{*}{5} & Union Square & $\begin{array}{l}\text { Important intersection. It is a historical landmark in } \\
\text { America }\end{array}$ \\
\hline & Little Italy & a dining and shopping area \\
\hline & Prince Street & an important shopping area \\
\hline & Top of the Rock & $\begin{array}{l}\text { an observation tower for city scenic viewing in New } \\
\text { York }\end{array}$ \\
\hline
\end{tabular}

